LIZARDS IN AN EVOLUTIONARY TREE 


\section{ORGANISMS AND ENVIRONMENTS}

Harry W. Greene, Consulting Editor

I. The View from Bald Hill: Thirty Years in an Arizona Grassland, by Carl E. Bock and Jane H. Bock

2. Tupai: A Field Study of Bornean Treeshrews, by Louise H. Emmons

3. Singing the Turtles to Sea: The Comcáac (Seri) Art and Science of Reptiles, by Gary Paul Nabhan

4. Amphibians and Reptiles of Baja California, Including Its Pacific Islands and the Islands in the Sea of Cortés, by L. Lee Grismer

5. Lizards: Windows to the Evolution of Diversity, by Eric R. Pianka and Laurie J. Vitt

6. American Bison: A Natural History, by Dale F. Lott

7. A Bat Man in the Tropics: Chasing El Duende, by Theodore H. Fleming

8. Twilight of the Mammoths: Ice Age Extinctions and the Rewilding of America, by Paul S. Martin

9. Biology of Gila Monsters and Beaded Lizards, by Daniel D. Beck

Io. Lizards in an Evolutionary Tree: Ecology and Adaptive Radiation of Anoles, by Jonathan B. Losos 


\section{LIZARDS IN AN \\ EVOLUTIONARY TREE}

Ecology and Adaptive Radiation of Anoles

Jonathan B. Losos

ㄸ

UNIVERSITY OF CALIFORNIA PRESS

Berkeley Los Angeles London 
THE PUBLISHER AND AUTHOR GRATEFULLY ACKNOWLEDGE THE GENEROUS CONTRIBUTION TO THIS BOOK PROVIDED BY

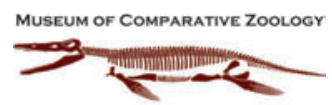

HARYARD UNIVERSITY

MUSEUM OF COMPARATIVE ZOOLOGY, HARVARD UNIVERSITY

University of California Press, one of the most distinguished university presses in the United States, enriches lives around the world by advancing scholarship in the humanities, social sciences, and natural sciences. Its activities are supported by the UC Press Foundation and by philanthropic contributions from individuals and institutions. For more information, visit www.ucpress.edu.

Organisms and Environments, No. Io

University of California Press

Berkeley and Los Angeles, California

University of California Press, Ltd.

London, England

(C) 2009 by the Regents of the University of California

All photographs are property of the author unless otherwise indicated.

Library of Congress Cataloging-in-Publication Data

Losos, Jonathan B.

Lizards in an evolutionary tree : ecology and adaptive radiation of anoles / Jonathan B. Losos.

p. $\mathrm{cm}$.

Includes bibliographical references and index.

ISBN 978-0-520-2559I-3 (cloth : alk. paper)

I. Anoles-Evolution. 2. Anoles-Ecology.

3. Anoles-Adaptation. I. Title.

QL666.L268L67 2009

$597.95^{\prime} 48138$ - dc22 2008027796

Manufactured in Singapore

I6 I5 I4 I3 I2 II IO O9

IO $9 \begin{array}{lllllllll} & 8 & 7 & 6 & 5 & 4 & 3 & 2 & \text { I }\end{array}$

The paper used in this publication meets the minimum requirements of ANSI/NISO Z39.48-I992 (R I997) (Permanence of Paper).

Cover illustration: Anolis monticola. Photo copyright Eladeo Fernández. 
To my wife, Melissa Losos, my parents, Carolyn and Joseph Losos, and my sisters, Carol, Elizabeth, and Louise Losos, for their love and support throughout my life 
The Page Left Intentionally Blank 